\title{
TOWARDS A PLANETARY SEMIOTICS
}

Per Aage Brandt ${ }^{1}$

\begin{abstract}
There exists a universal ecology-based stratification of levels of activity and meaning-making in human societies, a stratifying architecture that determines existing levels of social experience, types of sign functions and semantic functions in language, and finally the mental principles of human subjectivity. The planetary ecology of civilization is therefore constitutive of human semiotics. The following is a short outline of a theory of meaning based on these observations.
\end{abstract}

KEYWORDS: Global ecology. Dynamics of power. Meaning types. Semiotics of subjectivity. Semiotics of money.

\section{POR UMA SEMIÓTICA PLANETÁRIA}

RESUMO: Existe uma estratificaçâo universal baseada em ecologia dos níveis de atividade e criação de significado e efeitos de sentido nas sociedades humanas, uma arquitetura estratificante que determina os niveis existentes de experiência social, tipos de funçóes de signos e funçôes semânticas na linguagem e, finalmente, os princípios mentais da subjetividade bumana. A ecologia planetária da civilização é, portanto, constitutiva da semiótica humana. A seguir, é apresentado um resumo de uma teoria da significação com base nessas observaçôes.

PALAVRAS-CHAVE: Ecologia global. Dinâmicas de poder. Tipos de significados. Semiótica da subjetividade. Semiótica do dinheiro.

\section{The architecture of human ecology}

Meaning is the element that emerges when thinking creatures establish distinctions. We distinguish, as human beings, in our fundamental exchange

\footnotetext{
1 Case Western Reserve University, Cleveland - OH - United States. Adjunct Professor. Orcid: http://orcid. org/0000-0001-7774-5033.pabrandt18@gmail.com.
} 
with the extra-human world, between 1) what we have to take from it in order to individually survive, 2) what we need to extract in order to urbanize and reinforce our collective organization, and finally 3 ) what a third, very weird motive make us need to find and take in order to be able to live together at all under laws and sacred rules. The meaning of the distinction between these three ways in which we are bound to the extra-human world, Nature, is that of a universal ecological and semantic differentiation of a certain importance to human semiotics, as this essay will attempt to explain.

As all life forms, we extract from our material surroundings and expel what remains, 'waste', into the same surroundings. When pollution prevents continuing life in the same habitats, we move on and pollute somewhere else. However, these 'elsewhere' habitats are now getting filled up by polluted waste, which makes the fundamental ecological situation for human civilization global, that is, planetary. Not only do we tend to prevent ourselves from living here, but we prevent other species from proliferating or just surviving. The eco-semiotics of these exchanges turns into a socio-semiotic drama with specific structural properties that makes the case of human civilizations about as serious as that of the huge amounts of species we are now wiping out. It appears to be time to take a look at our actual planetary eco-sphere and, while widening the scope of the study of meaning, also get a chance to obtain a deeper understanding of the issues that our field-specific disciplines had left undiscussed.

We extract water and potential food, as all other species, so on this elementary organic level of life, we share their conditions. But we furthermore extract materials such as wood, stone, coal, oil, iron, which are not for nutrition, but for building protected habitats, agglomerations, towns, walled cities, and for the production of tools, machines, and the processing of all sorts of cultural goods pertaining to stabilized life forms. We may call this ecological stratum a political level, in a broad and general sense of polis; our activities on this level exceed everything other species can offer for comparison. Here are other important ways in which our civilizations are threatening other life forms, in particular by reducing their habitats. Finally, and last but not least, we extract a number of things from the surrounding ground that have no usage what so ever on the organic or the political level of our collective existence. We thus gather 'precious' metals and minerals that are universally interpreted as linked to symbolic practices, such as rituals and performative acts expressing authority and executive power. There is a universal 'transcendental esthetics' that associates effects of beauty with power and authority, as typically manifested by figurations of sovereignty and divinity adorned with these 'precious' entities. The architecture of ecological differentia- 
tion creating the three levels, which I therefore will call the organic, the political, and the symbolic, is a characteristic of human societies and has been so since the first civilizations, 50.000 years ago, approximately. In the modern world, this architecture creates a global socio-sphere covering the planet and common to all forms of society, across cultural, technological, ideological, religious, and economic differences. A planetary semiotics must therefore take this stratification as its point of departure; it can in fact be shown to ground the basic modes of meaning, functions of language, and types of signs. Organic meaning is existential, and affective, driven by moods, emotions, passions; political meaning is epistemic, truth-oriented and focused on possibilities; and symbolic meaning is performative, power-based and commanding. These differences pervade social life in any experiential scale.

\section{The dynamics of power}

The symbolic level of this basic stratification of human societies is where transcendent power is symbolized, universally manifesting two forms of sacredness : as sovereign law and as religious cult. ${ }^{2}$ The ruler and the priest wear different masks: one outfit expresses a warrior's sacred violence defending principles of rule and constituting the idea of a punitive Law applying on a territory; the other outfit expresses the embodiment of divine forces acknowledging the identity of persons entitled to live on the territory and bearing a Name to be called by and respond by. The first expressed principle posits a general status addressing all inhabitants across differences of status and is experienced and referred to as the Justice that underlies political Equality; but the second expressed principle instead introduces a singularity of persons or distinct social categories whose status calls for particular respect or disrespect according to the value of their name, their political Identity, underlying Freedom. Both principles, the Law (Justice $\longrightarrow$ Equality) and the Name (Identity $\longrightarrow$ Freedom), are needed for the inscription of individuals in a society distinct by territory and language; both are first of all based on interpretations of time: a profane calendar for history, evaluation of merit and punishment (in the shared past), a religious calendar for projecting events and rituals (in the shared future). Law and Name paradoxically are both necessary instances and yet are inherently contradictory, since the

\footnotetext{
2 I build the stratified analysis of social practice on Georges Bataille's heterology and on Michel Serres' 'natural contract' ideas. Their combination yields a coherent view of the fundamentals of social existence. The analysis of power that follows is my critique of Michel Foucault's view, which never takes the split within authority into account.
} 
former evaluates and treats persons according to what they $d o$, by Equality of actors, and the latter according to what they are, by Identity, whatever their acts are. Different forms of society will manage and mediate this contradiction between rulers and priests in characteristically different ways, and situations of fusion are likely to happen, as in most binary dynamic structures.

Once a power structure is established, its use of material and immaterial violence pervades not only the symbolic practices of a society but also its political structures and its organic base. Its language will "trickle down" through the political level and hit the basic level of everyday life of a population. When approx. 5.000 years ago - priests discover the popular attraction of the precious metals with which they cover the divine figurations, and they discover that small pieces of it can be used to "pay" the workers of the temples, because these pieces each carry magical protective power due to their figurative contact with the divine, they invent money, and money "trickles down" through the stratified social formation as well. ${ }^{3}$ Pieces of precious metal of this kind, 'money', can also be lent in important quantities in order for the wealthy to pay workers and soldiers the same way. Warriors ally with priests to guarantee that dept is paid, or (mortgaged) property taken over. ${ }^{4}$ When societies use this metallic means of expressing equivalence in commerce, on markets, in work contracts of all sorts ${ }^{5}$, in tax paying, mega-politic civilizations can grow and stay organized despite the complexity involved in urban growth and territorial protection and expansion. Money 'protects' its owners, according to its magical origin as a means of contact with the divine and transfer of divine force; it also indeed protects its owners by its "purchasing power" (Germ. Kaufkraft), which may be experienced as confirming the dynamic magic. It becomes a reference in its own right, not only a quantitative expression of value in goods and works. ${ }^{6}$ It is not only a quantitative sign of such value but also fundamentally a qualitative thing pos-

\footnotetext{
3 The etymology of the term 'money' refers to the temple of Juno Moneta, in Rome, where silver pieces were first coined. The goddess is said to have warned, and thereby protected, the population of an earthquake (from Latin: moneo, warn, remind, admonish). 'Money' then magically was believed to contain divine protection. Parallel stories may have existed in other parts of the Ancient world where similar 'monetary' practices emerged.

4 The class divide is a product of money, in the sense of "big money", capital, that is: enough to produce property, buy real estate, speculate or initiate commercial of industrial enterprises. The criterion is getting a loan of "big money". Agents who cannot get big loans, based on previously obtained or inherited property, become so-called proletarians, whereas those who can will become the "capital-ists". The primordial capitalists are thus the priestbankers. Religion and economy have always been two sides of the same...coin.

5 Paid work would then emerge as an alternative to slave-driven work. The evangelical parable of the vineyard workers is characteristic of this quantified idea of work time, which becomes a main motive of Marx' theory of surplus value.
}

6 Karl Marx failed to grasp the symbolic origin of money. 
sessing such value. Money is sign and thing in one. Hence the aporetic question of the 'value' of money itself. The aporia: What is the value of gold (as thing), expressed in gold (as sign)? The solution is that a standard quantum of gold does not have but instead is value, whereas the property (real estate) used as mortgage for substantial loans will further serve as measure of quantity of value, expressible in terms of gold and further in terms of currencies and bonds. ${ }^{7}$ Violence is implied; armed priests will take your valuable belongings if you fail to redeem a loan. No valuable belongings, no loan.

On the political level, a contradiction between the institutional (l)egalitarianism, on the side of Equality, and the singularizing libertarianism, on the side of Identity, is inevitable and gives rise to what modern parliamentary systems identify as "left wing" and "right wing" attitudes. The two pervasive semiotic media in modern societies, institutional discourse and private money, let the "left wing" appear discourse-dominated, while "right wing" will take on a less outspoken "economic", money-based profile, since money and property are identitary anchors, as opposed to laws and common interests, which depend on shared, intelligible and basically non-identitary, legalistic discourse.

On the organic level, the split between the two power forms is manifest in the contradictory relations between collaboration, solidarity, and elementary ethics of mutual help, on one side, and privacy, heritage, kinship-based affective behaviors, and moral signaling of distinction, pride, or privilege, on the other side.

This architecture of contradictory motives and principles, repeated and reinforced through the millennia, has created a corresponding, significant distribution of types of meaning, as manifested by the usage of signs and language.

\section{Signs and types of meaning}

Power does not argue, it declares, orders, calls, when addressing its target population. It parades and ritualizes. The corresponding uses of language are the imperative and the performative forms. Sentences of this kind do not have truth value but instead the modal meaning corresponding to instructions: you must do $\mathrm{X}$, you must not do $\mathrm{Y}$; $\mathrm{X}$ is deontically necessary, $\mathrm{Y}$ is deontically impossible; $\mathrm{X}$ is obligatory, $\mathrm{Y}$ is prohibited. Interestingly, such formulae do

\footnotetext{
7 Modern 'paper money' issued by state-backed banks therefore does not have to refer back to metal money, but as the great crises have shown only need state-backed violence to take over real estate if needed, and can speculate freely in terms of bonds bought and sold by other bonds, as long as there is property for the banks to take; speculation in urban real estate has reached astronomical levels during the last century, because it has become much 'safer' than investments in industrial production, and much better as mortgage for new bonds.
} 
not stress the first person but are typically impersonal; they let the force flow from a transcendent source toward the targeted second person. ${ }^{8}$ We may define performative dynamics and its injunctive enunciation 9 by this particular form of address, flowing apparently from the third person toward the second person through a transparent, mediator-like first person. ${ }^{10}$ This type of meaning can be directly related to the sign type we call symbols. A symbol is a type of signs we spontaneously recognize by its low criticality (a demonstratively non-similar sign relation between items in signifier plane and items in signified plane), also called arbitrariness, which shows us that it is 'coded' and issued by some conventional and identified instance. The authority of that instance is therefore the source of its deontic force. Examples include: traffic signs, signs in writing and counting, in musical and mathematical notation, and in sign language. The phonetic signifiers of names clearly belong to this category, and names are basically used for identifying and calling on persons. ${ }^{11}$ By analogy, words in general are used for identifying and calling up concepts in the mind, which might explain that lexemes and morphemes ${ }^{12}$ behave like other symbolic signs, as Saussure noticed, whereas sentences in general do not. Symbols are always the signs of some sort of power.

By contrast, the communication characteristic of social life on the political level is dialogical and discursive. It has to be argumentative and descriptive, because it must prepare decision making. The wide range of grammatical sentence constructions expressing reasoning by causal, conditional, concessive, hypothetical or counterfactual forms of imagination shows the predominance

\footnotetext{
8 There is no sentence saying *"I must you to X", because the source of the force is not the first-person subject; the second person becomes the grammatical subject in "You must...", "You can...", "You cannot..." etc., like in passive constructions; the role of the addressee is in fact to passively submit to the injunction. Brandt (2020) has a deeper analysis of the phenomenon in terms of enunciation dynamics.

9 Enunciation, French: énonciation, means the variable inscription and marking of the speaker's, the hearer's, and the possible third person's subjectivity and status in the expressed language, by personal pronouns, deictic adverbs or otherwise. In France, a considerable amount of research has been dedicated to the study of enunciational variations and structures, related to expressed meanings, discourse types, and situations of speech.

In this study, we may distinguish performative enunciation: the impersonal voice of authority speaks to first person: P3 $\rightarrow$ P1 (in the absence of a second person, P2); epistemic enunciation: P1, P2, P3 are in a triangular dialogical exchange, since P3 can be quoted; and affective-empathic enunciation: P1 $\longrightarrow$ P2 (backgrounding of P3). I have elaborated on the dynamics of enunciation in Brandt (2020).

${ }^{10}$ Hence, a threat is often softly formulated as a warning, or an (ironic) advice.

${ }^{11}$ Proper names also carry strong social, cultural or institutional connotations; persons entering into religious institutions, such as monks, nuns, popes, change their name.

${ }_{12}$ Morphemes as high-frequency signifiers of schematic structures may also be understood as the diagrammatic components of language. Whether infra-lexemic (as modifiers) or supra-lexemic (as phrase nodes), morphemes always introduce certain topological dimensions into sentence meanings (cf. the 'satellite' adverbs: up/down/ in/ out...).
} 
of epistemic modality in this mode of meaning. Political life has to depend on truth. ${ }^{13}$ Exchange of information, verification of news and rumors, critical debate, comparison of accounts and analyses, all this is required for the development of institutions and collective endeavors. Language as discourse unfolds as a support of knowledge and thinking but of course also as the framework of polyphonic drama, whether as lived in agora or staged as theater. The epistemic mode of meaning implies a full display of personhood in enunciation, first and second persons shifting in front of a third person actively targeted as 'object': the world as the overall shared challenge. Signs manifesting this mode of meaning are plans, maps, diagrams, that is, the mental and expressive graphics that immediately correspond to the cognitive workings of imaginative thinking. ${ }^{14}$ Symbolic threats to the epistemic life of a society often, even predominantly, come from the ways in which money interferes with both normative principles: by countering equality and limiting freedom.

Truth is to the political level what power is to the symbolic level. On the organic level, the organizing principle is of course existence itself. We produce and reproduce, collaborate and live in families: our stories are tales of work, worship, and love, as Freud said. Language is to be poetic or narrative here and telling is showing how existence can be understood. The corresponding mode of meaning is therefore basically mimetic; language is situational imagery and story, and signs are iconic. Icons feed directly into our memory and help build both our identities as historical 'selves' and our view of the world, shaped and reproduced by fictions, myths, pictorial, gestural, and monumental representations of more or less legendary figurativity. Iconic signs, including syntactic structures in language, signify by similarity to experienced content and therefore have high criticality (similarity between items in signifier plane and items in signified plane, point by point). Such signs do not process meaning by deontic or epistemic force but by affective impact: they are existential, and emotional, in the sense of affecting our sensibility and deep involvement with life and death as our bodily conditions.

So far, the ecological grounding of society as such yields a stratified view of implied principles, signs, and modes of meaning. The following graph sees the panorama in a modern context and from the political level, where the most prominent, dramatically conflicting influences are organic representativity from below and symbolic, authoritarian manipulation from above:

\footnotetext{
13 The contemporary crisis of 'fake news' therefore signals a structural decline of political life as such.

${ }^{14}$ See The chapter "Diagrams and Mental Figuration", in Brandt (2019a).
} 
Figure 1 - Social levels of meaning

\begin{tabular}{|c|c|c|c|}
\hline \multirow{3}{*}{$\begin{array}{l}\text { Social } \\
\text { levels } \\
\text { of } \\
\text { meaning }\end{array}$} & & $\begin{array}{l}\text { POWER } \\
\text { Symbolic level: Law } / \text { Name }=\text { deontic force }\end{array}$ & PERFORMATIVE meaning \\
\hline & 1 & $\begin{array}{c}\text { TRUTH } \\
\text { Political level }: \text { Discourse = epistemic force }\end{array}$ & INFORMATIVE meaning \\
\hline & & $\begin{array}{c}\text { EXISTENCE Democratic representativity } \\
\text { Organic level: Narratives }=\text { affective force }\end{array}$ & FORMATIVE meaning \\
\hline
\end{tabular}

Source: Author's own organization.

Under the dual symbolic determination, thinking in the social life develops egalitarian and 'identitarian' motives and corresponding contradictions, while also subsuming concerns and initiatives from the population's organic groups of interest and collisions of wealth and misery. Semiotically speaking, an iconic mass of stories, myths, songs, and fictions nourish the political sphere's imaginative conceptual, diagrammatic elaborations, which are at the same time determined by the overarching power structure's symbolic performatives.

Through world history, each part of the planetary socio-sphere has developed particular solutions to the problem of stabilizing the dynamics of the inherently contradictory forces involved in the fact of being a country, a nation, a culture, more or less isolated. The "modes of production" have involved despotism and slavery, feudalism and serfdom, capitalisms and socialisms of different types with corresponding repression forms and variants of exploitation of the populations' work force. Each mode has developed its particular conceptions of law, sacredness, money, property, rights and duties, kinship, ethics and morals, art and folklore. During the last 500 years of 'modernity', political structures reached a high degree of integration or at least interaction in a globalized civilization 'united' by extensive mutual wars and fights for markets, and presently, the symbolic level has territorially become truly spherical in the sense of uniting capitals and financial systems in a planetary network that deeply affects political forms worldwide, leaving local populations disoriented. Its arbitrary monetary and 'growth'-oriented dispositions affect the planetary ecology by changing its climate, reducing its fauna, flora, and conditions of life in general. Populations now mobilize trans-locally to join forces and try to protect the shared ecological conditions against the planetary, symbolically determined destruction. The problem involves a growing contrast between the spherical finiteness of planetary resources and the infinite pretensions of linear capital expansion, whether purely numerical, speculative, 
thereby increasing abstract power, or else productive and thereby increasing material pollution and biological destruction.

In this situation, it is important to understand the material conditions we share as inhabitants of the planet Earth. And to do so, it is useful also to understand the immaterial conditions we share as citizens of the global sociosphere. The latter is an immediate semiotic task, and it leads to the question of subjectivity: how do we inscribe the subject in this context?

\section{On subjectivity}

The modes of meaning that social life for fifty millennia has reinforced in our minds and brains have shaped an architecture of our subjectivity that copies the architecture of the socio-sphere, I will argue. As subjects, we in fact live in an organic present time, in which we experience our body and conduct its interactions with others and our material circumstances - this is our personal eco-sphere, so to speak. Our sensory perception is directly related to our acts, which we have to plan and monitor, in the perspective of their circumstances in place and time. In this organic iconicity, we are part of the 'picture' we perceive. This is the phenomenological mystery of being conscious. We visually perceive our surroundings from our bodily point of view but at the same time from an imagined position which is much richer than the visual and the proprioceptive percept in each second. We complete the landscape around us and insert ourselves with our others in it, which gives us an immediate situational perception that can carry existential meaning for us. Thereby, we concatenate perceived situations and remember them as scenarios, episodes, and larger narratives, containing ethical and moral meaning. ${ }^{15}$ However, when we allow ourselves to develop these narratives or simply concatenated situations counterfactually, we need to activate something else, namely a conceptual imagination based on epistemic assumptions and thinking in terms of pure possibilities. Iconic figuration then slides into 'thinner' schematic mental diagrams, as hypothetical alternatives to experienced contents are lined up and considered. This is often necessary for making plans or just deciding 'what's next' in our line of action. Playing chess is a nice example, and we may indeed 'play chess' in many political or everyday strategic situations that call for careful interaction. ${ }^{16}$

\footnotetext{
${ }^{15}$ Again: ethics concern our responsibility for taking care of the other; morals concern our identitary bonds to the groups we are in. The contradiction is often radical between ethical and moral claims.

${ }^{16}$ See "What is a Game?", in Brandt (2018).
} 
We may also, as subjects, shift to a symbolic position. This happens when we address others in the name of some authority and enounce an injunction, negative or positive, in the imperative mood, by gesture, or otherwise. The socalled speech act force is symbolic in this sense.

The iconicity of the organic social level and this iconicity of individual sensory perception and bodily experience of actions in real time are semiotically prepared to merge. ${ }^{17}$ So the subjective experience will contain echoes of circulating fictions, narratives, images, and myths of all kinds. Furthermore, the social symbolicity of the level of overarching powers will communicate with the subjective symbolicity of deontic language and acts of injunction. The individual is likely to take over the style of actual rulers and priests in the shaping of personal gestures of control and commanding. ${ }^{18}$ No mental effort is needed in order to 'project' social power, for example patriarchal or class styles, into individual behavior. In this sense, subjectivity is a socio-sphere in miniature, or a 'mirror' of a given society. A considerable mental effort is even needed not to do so. The fundamental difference between a given society and an individual subject living in it is of course that the latter has an inner life! ${ }^{19}$ The decisive instance in the self-editing of this inner life is the epistemic semiotics that connects society and individual: the collective process of finding truths and possibilities in order to make decisions concerning the political life of a society and, on the other hand, the individual process of understanding the surrounding world well enough to be able to live in it, are intensely related and interdependent. Truth is vital in both processes. However, what the individual mind takes over from social iconicity and symbolicity depends dramatically on the individual epistemic filter of the mind, that is, thinking. We perceive, act, and think simultaneously. Perception and action are therefore closely connected and modify each other within seconds. Thinking, however, needs distance and much more time and is mainly either retrospective (evaluating) or prospective (planning); the present act is procedural and reflexive rather than reflective, which is why social impulses often escape the critical, reflective, conceptual filter when action is fast, intense, and collec-

\footnotetext{
${ }^{17}$ In cognitive terms, there is no collective iconicity without the individual iconic capacity to form and understand images and thereby connect them to real or possible perceptions. A drawing of a face has to undergo completion by the mind in order to 'mean' a face. Cognitive completion allows us to 'see' things and watch or be in situations very partly simulated. The same completion happens in the reception of language, which simulates very few selected features of a scene. Syntax imposes radical reduction of the information, but even so, we are (often) able to guess the meaning of sentences, by completion.

${ }^{18}$ People wearing uniforms are even supposed to duplicate the style of power expression of their social souverains while in office.

${ }_{19}$ Another difference is that the global ecology is in general hidden to the local citizen, except in his own area of work experience.
} 
tive. We are particularly vulnerable in the present moment, in 'real time', as the phenomenon of irrational group behavior shows. Such experiences of intense and irrational presence are typically marked by the feeling of intersubjective fusion: "we are one".

Symbolic and iconic signs easily merge in the mind, through the mechanism described by Roland Barthes, after Louis Hjelmslev, as connotation: the sign becomes the signifier of another sign; more accurately, the icon (or iconized symbol) becomes the signifier of a symbol. In this constellation, the affective impact of the icon merges with the deontic effect of the symbol, and what you see becomes what you must do, have or be. This effect is well-known from advertising, propaganda, and ideological fiction. By contrast, the diagrams of thinking, and thereby thinking itself, depend neither on symbols, nor on icons or symbolizing icons. This is extremely important. Whereas symbols anchor their meaning in local power structures and constellations, 'from where they speak', as Foucault would have it, and whereas icons ground their meaning in shared feelings, by contrast the internal and external signs that epistemic thinking uses remain in principle unanchored, unbound by such ties, if these signs are allowed to unfold; they then reach out towards a global horizon of possibilities and impossibilities. Thinking is thus by its very nature in a semiotic position from where a critical stance to given manifestations of meaning is possible. We see this happen in science, mathematics, philosophy, and art, as well as in everyday political or philosophical discussions and deliberations. While the deontic and the existential modes remain bound to their local social and historical frames, the epistemic mode of meaning is in fact potentially global, planetary. Therefore, it is often a threat to local structures, as history shows, and object to suspicion or persecution. Locally negative, critical thinking is considered as dangerous.

In the architecture of the human mind, thinking even separates existential feelings and pragmatic performatives, in the same way as in the socio-sphere, where the epistemic initiatives are regularly fragilized from above and from below (in the vertical axis of model). In the individual mind, determined by the function of human memory, the existential 'pinacothèque' constitutes the episodic and auto-biographical, deep layer of long-term memories, which are not always accessible to voluntary recall, and sometimes, if hardly retrievable, described as pertaining to a certain 'Unconscious' ${ }^{20}$ The pragmatic surface of our present doings is predominantly symbolic, as mentioned, which is why ideologies and

\footnotetext{
${ }^{20}$ Epistemic thinking can also be unconscious to a certain point, but most dreams are apparently deontic (symbolic) and affective (iconic). Freud's Unconscious seems to prefer the affective (libido, desire), whereas Lacan's Unconscious prefers the symbolic (the paternal Name, etc.).
} 
figurative connotations so easily take over our life, if the cogito that separates the non-epistemic modes of meaning is not active. Neologisms may be of little use here; but allow me to hammer out this point by characterizing the pragmatic symbolicity as our agito, our agentive drive), opposing both this epistemic cogito and the background emotional libido, which tends to obtain local fusions with contents of the agito (as 'acting-out'), if not inhibited by the intermediate cogito. The architecture superposing the cogito on the agito, and again the libido on the cogito, creates a triad of instances comparable to that of the socio-sphere that has created it - but in the scale of subjectivity, we might say that it walks on its head, since the symbolic (pragmatic) instance is the most 'concrete', and the mnemonic, iconic (libidinal) instance the most 'abstract', whereas thinking is, just as in society, the medium that separates them. We might summarize the dynamic relations between social and subjective structures in a diagram as the following (Fig. 2):

Figure 2 - Social and subjective levels and determinations

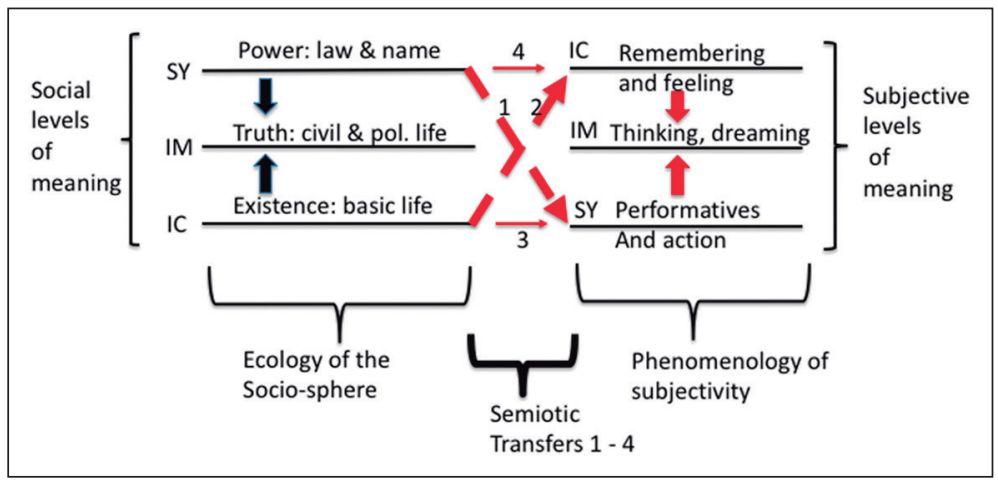

Source: Author's own organization.

The double determinations or transfers (T1 \& T3, T2 \& T4) are of course due to the influences of organic collective life on individual existential life, and to the influences of symbolic collective practices and rituals on the iconic individual emotional life (as we see in religion). ${ }^{21}$ Still, any individual subject will

\footnotetext{
${ }^{21}$ Transfers from the social to the subjective system: a typical example of T1 would be war - the subject 'serves' (SY) as a soldier of a country (SY). A strong example of T2: love - an existential and sexual encounter (IM) is engraved in the 'heart' (IM) of the subject. As to T3: childhood - the socio-biographical experience of the subject's early years (IM) determines the voluntary adult actions (SY) of the subject. And T4: cult - the postures of power (SY), its commanding pomp and circumstance, 'impress' the subject and produce an affective binding (IM). These types of transfer are only basic forms, and reality may be considerably more complicated. They are semiotic, since meanings get embedded in meanings through the syntax of signs containing signs (BRANDT, 2019b).
} 
want to not only 'belong' to a society and thereby be a target of social influences that have inhibiting effects on thinking and creating, as indicated, but will wish to inversely influence the 'world': anyone wants to 'make one's mark'.

The semiotic transfers are practically made when social signs, for example identitary emblems, religious markers etc., are individually used, and as often as socially generated language is repeated in the register of face to face communication. To reverse this process (that is, to invert the direction of the red arrows in Fig. 2) is not an easy task, but the history of ideas seems to show its possibility. The thinking of the individual Enlightenment philosophers is an epistemic achievement that had and still has considerable social effects in and across many societies. Writers, artists, thinkers and 'intellectuals' often gain significant impact when social life is in turmoil and its discourses are destabilized. ${ }^{22}$ But when in such turmoil the singular epistemic voices are silenced, then rational political life as well collapses, and the organic merges socially, not only individually, with the symbolic; the result is always irrational, and often catastrophic. ${ }^{23}$

\section{On philosophy, briefly}

While our planet is burning and life in all forms starts drowning, suffocating, dying in our waste, theoretical concerns of international discourse still mainly run in one direction: growth of global capitals and monetary power, rather than in the opposite direction: humanism and ecological rationalism. The madness of money has largely exiled the principles of humanism, responsible ethics and care for the truths that we need to share in order to assure the habitability of this world (formerly known as 'sustainable' economies). Instead, we get management (symbolic) and mindfulness (iconic). A critical ecological view of social life in the perspective of the agonizing planetary socio-sphere presupposes a recognition of the autonomous existence of epistemic meaning, the cogito. Why would this view not be self-evident? ${ }^{24}$

\footnotetext{
${ }^{22}$ Foundational thinking originates, I suppose, I the terrible feeling of collapsing thought and hence a need for epistemic rebuilding in order to re-separate the symbolic and the iconic layers. In the intimacy of subjectivity, sexuality seems biologically linked to a similar but momentary collapse reuniting symbolic (libido) and iconic (agito) drives. Passions of this kind can be violent. And 'sexuality is generically stupid'.

${ }^{23}$ Populisms such as historical fascism, falangism, nazism, islamism etc. all manifest this fusion of the symbolic and the organic levels of meaning, short-circuiting the epistemic level - hence the explosion of lies and delirious propaganda they stimulate. Existential philosophers, such as Nietzsche, Heidegger, and Sartre, unfortunately did not see this, but their negligent attitude to truth is characteristic.

24 The linguist-philosopher Jerrold Katz wrote a wonderful treatise on The Metaphysics of Meaning (KATZ, 1990) containing a brilliant critique of anti-cogito thinking in analytic philosohy.
} 
There exist in our philosophical modernity two main versions of rationalism, both first clearly conceived in the 17 th century, and both bound to become predominant 'metaphysical' bases of newer philosophical trends of different kinds. One is René Descartes' cognitive dualism in the Meditationes, and the other is Baruch Spinoza's mystical monism, in his Ethica. Cartesian rationalism was mainly developed in European philosophies, whereas Spinozist rationalism gave rise to the varieties of Anglo-Saxon analytic philosophies. The fundamental question concerns the way to conceive the relation between two elementary forms of substance - mind and matter - or as Descartes termed it, between res cogitans (mind) and res extensa (matter). Thoughts and physical things are both real, or substances, but evidently not in the same way. How is this relation then to be understood?

In monist thinking, concepts and the things they refer to are one (Greek: monos, "alone"), that is, materiality and idea are aspects, or attributes, of one same substance, so everything is idea, and everything is matter. Since concepts therefore are situated in the physical world, reality is conceptual and logical as a whole. Some of this world-logic enters the human mind through the body and can make us think. Logical empiricism therefore ties thinking to direct bodily experience and denies any autonomous epistemic universalism or independent dimension of thought: such 'theory' is termed 'metaphysics' and considered bad for mankind. Non-local ideas are unclear and unhealthy. ${ }^{25}$ The result is that meaning is only considered pragmatically, empirically, or in semiotic terms, iconically, symbolically, but not diagrammatically: no autonomous cogito is allowed. Therefore, no ecological dimension is developed, since this would contradict the militant pragmatics of this bodily style of thinking. ${ }^{26}$ Its immediate advantage for the believers is, in return, a reconciliation of thought and religion (which pleased Leibniz: the world seen as God's thinking) and of thought and money: a coin is 'monistic' in itself, so to speak, being both a material thing and a concept, an immaterial value. Money is the embodiment of divine protective force - and is therefore in itself a powerful philosophical argument. Homo ceconomicus is born and conceived as a monist.

\footnotetext{
${ }^{25}$ Spinoza has to avoid saying that they are false, of course, since falsehood would entail representational autonomy. Either they are true, or they are nonsensical. Nonsense replaces falsehood. So 'metaphysics' is 'nonsense'. 'Nonsense' becomes an invective. In his logical epistemology, meaning is necessarily truth. Modern Spinozists do not accept the autonomy of mathematics but insist that logic and math are ontologically the same thing (Russell and Whitehead's Principia Mathematica), and that thing is the world.

${ }^{26}$ So, in contemporary terms, there is no climate crisis, unless your body can sense it; but temperatures around my body are rather normal, therefore there is no crisis.
} 
In dualist epistemic thinking, an immaterial reale such as a piece of knowledge or information, a mathematical equation, or a musical score, is not an aspect of a thing but a representation of a thing. A representation projects from one substance to the other, so to speak. A representation can be false; whereas monism does not recognize falsehood but prefers to term it 'vagueness' (versus clarity). ${ }^{27}$ However, subjectivity is meaningless without a representational epistemic reality; the instance that lets human beings be different from their social conditions is their autonomously thinking mind rather than its bodily host. The human imaginary, including the capacity to imagine non-actual possibilities, and to understand that a belief can be wrong (false), is crucial to the existence of the critical force of a thinking mind. In dualist rationalism, for example in phenomenology, representations are considered as based both on perception and on conceptual schematization, as demonstrated by language: grammar has lexical input from our categories the experienced world but assembles its units through morphological activation of generic, schematic signs. Language is a simulation of thought. Every human being can think - categorize and schematize - and, as the human rights tradition emphasizes, should be respected without regard to ethnic, gender, class or other identitary criteria. This is the ethical principle underlying humanism and its homo cogitans. In this sense, humanism is ontologically (metaphysically) dualistic.

Homo ceconomicus thus opposes homo cogitans in the same way as the logic of money opposes truth-oriented reason; as ethnic concerns oppose ethical concerns; as monism opposes dualism; and as global economy opposes planetary ecology. ${ }^{28}$

Within semiotics, the concept of meaning is implicitly interpreted in the monistic key by the school of bio-semioticians, who wish to foreground the idea of a continuity of life spanning from the simplest organisms through all parts of the living world to human beings, cultures, and languages. In this view, meaning is explicitly anchored in the activity of specific organisms as what connects individuals to conspecific individuals, species to other species, and different local bio-spheres to each other. Meaning expresses itself, it is suggested, in all biological exchanges, whether chemical, mechanical, or behavioral. Meaning, here, is clearly not representational: it has no content and essentially just 'means' itself. Curiously, but characteristically, bio-semiotics has not developed non-local

\footnotetext{
${ }^{27}$ In existential philosophy, the difference becomes a distinction between authenticity and inauthenticity (alienation).

${ }^{28}$ How is the mind technically related to the body? Descartes suggested that the nerves were involved. But how precisely? This is still an open question, and one whose answer may come from correlative studies in neurophenomenological research (what is going on where, when, and how?).
} 
ecological perspectives. Its vitalism establishes instead a hard boundary between the animate and the inanimate world and keeps all of its interest within the animate continuum. Therefore, the fate of the planet itself, under the weight of this continuum, does not deserve its attention. I would rather suggest considering this school as a form of bio-pragmatic cybernetics.

Semiotics in the linguistic tradition, by contrast, is content-oriented and, with a cognitive perspective added, also open to the biological dimension, albeit in a different key, since meaning is here a matter of minds and brains, which many animal species have, in beautifully variable forms. As mentioned, human meaning production includes cogitative imagination, not only finding and knowing facts (iconic) and giving orders (symbolic) or obeying them; and such minds are therefore able to transcend their bio-environmental niche and grasp wider horizons, including problems that haunt the niche of all niches, the planet. The socio-sphere that covers our planet and whose material interaction with human societies created the architecture of our semio-sphere and its modes of meaning, as well as that of human subjectivity, is furthermore a necessary starting point for a general semiotics. ${ }^{29}$

\section{Critical conclusive comments.}

The above delineates a view and outlines a way of doing semiotics that is not usual. Standard semiotics can be seen as limited in certain respects. Either it only studies the semio-logic of reasoning (Peircean semiotics) or only the semiotics of discourse (Saussurian and Greimasian semiotics). In both cases, it ignores the most important tasks and goals of a science of human realities. These realities, or objects, include 1) the nature of socio-cultural reality (what is a society and a culture made of?), 2) the nature of language and signs (what is language, what is semiosis made of?), and 3) the nature of subjectivity, mind, and psyche (what is a mind, what is affectivity, what is intersubjectivity made of?). Semiotics must contribute to and learn from existing studies on the structural nature of these realities.

Semiotics, so far, has been uninterested in addressing these questions or fields: socio-anthropology, linguistics, psychology. In all cases, to all of these questions, its answers have invariably been "logic" or "discourse". Despite being a general study of meaning, it has had minimal impact in the fields of sociology,

\footnotetext{
${ }^{29}$ The difference between $a$ society and the socio-sphere is made dramatically clear by the migrants from zones exposed to war, inter-ethnic destruction, and climatic catastrophes. The new planetary homo migrans lives directly in the socio-sphere.
} 
linguistics, psychology (incl. psychoanalysis). ${ }^{30}$ Semiotics has not had the capacity to interact epistemically with other disciplines committed to the endeavor of studying these aspects of the human world. Asked what is 'society', what is 'language', what is 'psyche', it has had very little to say. In philosophy, it has supported standard pragmatics or standard empiricism or hermeneutic empiricism; even phenomenology is left untouched by semiotics (except in the case of Merleau-Ponty). Asked what ecology is - the question above all other urgent questions in the contemporary political world - it suggests that it is a compelling notion (in logic), a compelling theme (in discourse), not discovering or embracing the idea that it is, referring to the planetary condition of human civilization, a fundamental and rather dramatic evolutionary process that created the structured nature of meaning itself.

Last but not least, current semiotics has had little to say about money. ${ }^{31}$ Semiotics has never challenged economics; it discusses 'values' as moral entities but not the intriguing monetary phenomenon itself. ${ }^{32}$

A planetary semiotics grounded in planetary ecology and maintaining a planetary scope in the study of the realms of power, language, subjectivity, communication, and the existential dimensions of meaning, by contrast, opens the inquiry to forms of research including these major components of the human and animated world. The stratification of the socio-sphere, the modes of meaning existing in the subsequent semio-sphere, the contradictions inherent in the stratified historical societies ${ }^{33}$, the functions of language, and the dynamics of subjectivity: all of these factors are aspects of our human reality, which in this perspective constitute a consistent structural whole and may be addressed on the base of a unified ontology. While methodologies vary according to the specificities of subfields and the inventivity of its researchers, an ecologically based global ontology is a prerequisite for a dynamic semiotic approach meeting the

\footnotetext{
${ }^{30}$ We might well speak, by prefixes, of socio-semiotics, psycho-semiotics, and semio-linguistics, but these specializations stay within the guarded domain of plain standard semiotics.

31 In philosophy, Hénaff $(2002,2012 a)$ contributes substantially to the thematization of money as discussed in the tradition from Plato to Searle, and from Marcel Mauss to Lévi-Strauss. Hénaff (2012b) is a beautiful introduction to the great philosopher of the global world, Michel Serres.

32 The remarkable exception is Lamizet (2013, p.21, italics are mine), a monumental critical analysis of value, meaning, semiotics and political economy. Still, this work stays in the realm of "the political language of economics". Money and monetary value are interpreted as manifestations of fetishism in the psychoanalytical sense, and Lacan is strongly present in the references.

33 Again, these include: symbolic contradictions between legal and religious violence (Law and Name); political contradictions opposing claims of equality and of freedom; organic contradictions between ethics (solidarity, community) and morals (particularity, property). These are unsolved and probably insoluble. Their mutual intrigues and alliances have occupied humanity throughout history, but they all now require drastic reformulation in the light of homo migrans (see above) and the ecological state of the planet.
} 
challenges of the humanities and the social sciences in the age of a crisis destabilizing both 'spiritual' and material life on the planet Earth.

The foundational problems of society, semiosis, and subjectivity have stayed opaque as long as they were mutually isolated. Taken together, they illuminate each other and give rise to a planetary-based, comprehensive and critical form of thinking, which I would certainly still call semiotics.

\section{Afterthought}

The semiotic status of art, including literature and music, is that it has a scope integrating the symbolic, the epistemic-political, and the iconic-organic meaning levels in ways that depend intensely on the transfers between the social and the subjective registers in the artist's and the receiver's lives. Art is therefore eo ipso even more sensitive to global ecology than any other semiotic practice, which adds to the list of contradictions a dynamic socio-spheric opposition of two major forces - the force of human violence and that of natural violence. Nobody will escape experiencing the clash of these forces. Art already fights within it, on one side or the other. This is thus, on may say, aesthetics in a new key, and a new key to the metaphysics of meaning.

\section{REFERENCES}

BRANDT, P. A. La dynamique énonciative de la subjectivité. Actes Sémiotiques [En ligne], Limoges, n.123, 2020. Available at : https://www.unilim.fr/actessemiotiques/ $6405 \&$ file $=1$. Accessed on: Mar. 2020.

BRANDT, P. A. The Music of Meaning: Essays in Cognitive Semiotics. Newcastle upon Tyne: Cambridge Scholars, 2019a.

BRANDT, P. A. From Linguistics to Semiotics: Hjelmslev's Fortunate Error. In: HÉNAULT, A. (éd.). Le sens, le sensible, le réel : Essais de sémiotique appliquée. Paris: Sorbonne University Presses, 2019b. Quatrième partie.

BRANDT, P. A. What is a game?: A Ludo-Semiotic Approach. Language and Semiotic Studies [online], Suzhou, China, Winter 2018. Available at: http://lass. suda.edu.cn/_upload/article/files/b1/41/2ade60054bb8b3190cbbb34fc45a/1308db ae-d692-4eb9-b411-24121e777159.pdf Accessed on: 10 Apr. 2020.

HENAFF, M. Le Don des philosophes : Repenser la réciprocité. Paris: Le Seuil, 2012a. 
HENAFF, M. Naissance du monde global : Actualité de Michel Serres. Paris: Bourin, 2012b.

HENAFF, M. Le Prix de la Vérité : Le don, l'argent, la philosophie. Paris: Editions du Seuil, 2002.

KATZ, J. J. The Metaphisics of Meaning. Cambridge, Mass.: The MIT Press, 1990.

LAMIZET, B. Le Sens et la Valeur : Sémiotique de l'économie politique. Paris: Classiques Garnier, 2013. 